\title{
PENGARUH PENGELUARAN PEMERINTAH SEKTOR PENDIDIKAN, KESEHATAN DAN TPAK TERHADAP IPM DI INDONESIA
}

\author{
Ulfa Maulina $^{\mathrm{a}^{*}}$, Devi Andriyani ${ }^{{ }^{*}}$ \\ a Fakultas Ekonomi dan Bisnis Universitas Malikussaleh \\ $a_{*}$ Corresponding author: devisep80@ gmail.com \\ $a *$ ulfamaulina520@gmail.com
}

\section{A R T I C L E I N F O R M A T I O N}

Keywords: Government

Expenditures of education sector, Health, Level of Labor Participation, Human Development Index.

\section{A B S T R A C T}

This study aims to determine the effect of government spending of education sector, health and level of labor force participation on human development index in Indonesia. This study used time series data from 2005 to 2019. The method of data analysis uses multiple regression analysis. The results of partially show that government expenditure of education sector has a negative and significant effect on human development index in Indonesia, government spending of health sector has a positif and significant effect on human development index in Indonesia, and the level of labor participation has a positive but insignificant effect on human development index in Indonesia. Simultaneously, government spending of education sector, health, and level of labor participation have a positive and significant effect on the human development index in Indonesia.

\section{PENDAHULUAN}

Permasalahan yang paling banyak dihadap1 oleh Negara berkembang adalah masalah pembangunanan, salah satunya adalah Indonesia. Negara Indonesia masih banyak melakukan pembangunan di berbagai bidang guna mewujudkan masyarakat yang lebih makmur dan sejahtera. Suatuu negara dikatakan maaju bukan saja dihitunng dari pendapatan domestik bruto saja tetapii juga mencakup aspek haraapan hidup serta pendidikan masyarakattnya. IPM adalah suatu tolak ukur angka kesejahteraan suatu daerah atau negara yang dilihat berdasarkan tiga dimensi yaitu: angkaa harapan hiidup paada waktu lahir, angka haraapan lama sekolaah dan rata-rata lamma sekolah, dan kemampuan daya beli(Putri 2018).

Berikut ini adalah Perkembangan Indek Pembangunan Manusia di Indonesia tahun 20102019

\begin{tabular}{|c|c|}
\hline Tahun & $\begin{array}{c}\text { Indeks Pembangunan } \\
\text { Manusia } \\
(\mathbf{\%})\end{array}$ \\
\hline 2010 & 66,53 \\
\hline 2011 & 67,09 \\
\hline 2012 & 67,7 \\
\hline 2013 & 68,31 \\
\hline 2014 & 68,9 \\
\hline 2015 & 69,55 \\
\hline
\end{tabular}

\begin{tabular}{|l|l|}
\hline 2016 & 70,18 \\
\hline 2017 & 70,81 \\
\hline 2018 & 71,39 \\
\hline 2019 & 71,92 \\
\hline
\end{tabular}

Sumber: Badan Pusat Statistik, 2020

Merujuk data dari BPS Indonesia (2020) pada Tabel diatas dapat diketahui bahwa IPM di Indonesia dari tahun 2010 sampai 2019 terus mengalami peningkatan setiap tahunnya. Pada tahun 2017, IPM Indonesia mencapai 70,81. Angka inni meningkatt sebeesar 0,63 poin ataau tumbuh sebesar 0,90 persen dibandingkan tahun 2016. Bayi yang lahir pada tahun 2017 memiliki harapan untuk dapat hidup hingga 71,06 tahun, lebih lama 0,16 tahun dibandingkan dengan mereka yang lahir tahun sebelumnya. Anak-anak yang pada tahun 2017 berusia 7 tahun memiliki harapan dapat menikmati pendidikan selama 12,85 tahun (Diploma I), lebih lama 0,13 tahun dibandingkan dengan yang berumur sama pada tahun 2016.

Menciptakan sumberr daya manusiia yang berkualitass dibutuhkan berbagai sarrana dan prasaraana. Oleh karenanya dibutuhkan investasi untuk dapat menciptakan pembentukan sumber daya manusia yang berkualitas seperti investasi pada sektor pendidikan dan kesehatan. Dimana 
pendidikan dan kesehatan merupakan tujuan pembangunan yang mendasar disuatu wilayah. Dengan demikian untuk mendukung aspek pendidikan dan kesehatan maka dibutuhkan anggaran. (putri, dkk. 2018)

Berikut ini perkembangan pengeluaran pemerintah di Indonesia.

Perkembangan PengeluaraPemerintah Sektor Pendidikan dan Kesehatan Tahun 2010-2019

\begin{tabular}{|c|c|c|}
\hline Tahun & $\begin{array}{c}\text { Pengeluaran } \\
\text { Pemerintah } \\
\text { Sektor } \\
\text { Pendidikan } \\
\text { (Milyar } \\
\text { Rupiah) }\end{array}$ & $\begin{array}{c}\text { Pengeluaran } \\
\text { Pemerintah } \\
\text { Sektor } \\
\text { Kesehatan } \\
\text { (Milyar } \\
\text { Rupiah) }\end{array}$ \\
\hline 2010 & 90818,31 & 18793,02 \\
\hline 2011 & 97854,05 & 14088,77 \\
\hline 2012 & 105207,55 & 15181,70 \\
\hline 2013 & 119604,23 & 38077,20 \\
\hline 2014 & 126314,68 & 49379,19 \\
\hline 2015 & 146134,75 & 51426,33 \\
\hline 2016 & 131973,95 & 59639,01 \\
\hline 2017 & 138507,30 & 57225,07 \\
\hline 2018 & 145941,72 & 61869,74 \\
\hline 2019 & 152690,05 & 62758,35 \\
\hline
\end{tabular}

Sumber; BPS, 2020

Merujuk data dari BPS Indonesia 2020 pada Tabel diatas dapatdiketahui bahwa pengeluaran pemerintah sektor pendidikan dan sktor kesehatan di Indonesia dari tahun2010 sampai 2019 mengalami kondisi yang fluktuatif. Pengeluaran pemerintah sektor pendidikann padatahun 2010 sebesar Rp. 90818,31 Milyar menjadi Rp.152690,05 Milyar ditahun 2019. Sedangkan disisi pengeluaran pemerintah sektor kesehatan juga meningkat setiap tahunnya, tahun 2010 pengeluaran pemerintah sektor kesehatan sebesar Rp.18793,02 Milyar menjadi Rp.62758,35 ditahun 2019. Pada umumnya pengeluaran pemerintah akan membawa dampak positif pada pertumbuhan ekonomi, dengan adanya pengeluaran pemerintah akan menciptakan berbagai prasarana untuk mengatasi perekonomian yang lambat dalam suatu pembangunan (Sukirno, 2015)

Selain itu, Tenaga kerja merupakan faktor terpenting dalam kegiatan perekonomian sebagai sarana dalam satu kegiatan seperti produksi, tenaga kerja dianggap lebih penting dari pada sarana produksi dimana tenaga kerja sangat menentukan maju mundurya suatu wilayah.meningkatnya jummlahangkatan kerja dari tahun ketahun diharapkan dapat berpengaruh terhadap TPAK. Tingkat partisipasiangkatan kerja merupakan penduduk usia kerja aktif dipasar tenaga kerja baiik yang sedang bekerjaa atau mencarii pekerrjaan yang memberikan ukeuran relatif dari pasokani tenaga kerja yang tersedia untuk terlibat dalam produksii barang dan jasa. (BPS, 2012).

Berikut ini perkembangan tingkat partisipasi angkatan kerja di Indonesia.

\section{Perkembangan Tingkat Partisipasi Angkatan Kerja di Indonesia Tahun 2010-2019}

\begin{tabular}{|c|c|}
\hline Tahun & TPAK (\%) \\
\hline 2010 & 67,23 \\
\hline 2011 & 66,78 \\
\hline 2012 & 67,76 \\
\hline 2013 & 66,77 \\
\hline 2014 & 66,60 \\
\hline 2015 & 65,76 \\
\hline 2016 & 66,34 \\
\hline 2017 & 66,67 \\
\hline 2018 & 67,26 \\
\hline 2019 & 69,32 \\
\hline
\end{tabular}

Sumber: BPS. 2020

Merujuk data dari BPS Indonesia 2020 pada Tabel diatas dapat diketahui bahwa TPAK di Indonesia dari tahun 2010 sampai 2019 mengalami fluktuasi. Penurunan TPAK di indonesia terjadi Pada tahun 2011, 2013, 2014 dan 2015. Selain itu hal yang dapat mempengaruhi TPAK dapatdilihat dari IPMnya. Mengutip berita dari Kemenkeu menyebutkan bahwa Badan Pusat Statistik (BPS) tahun 2018 merilis data dalam setahun terakhir, dimana pengangguran berkurang 50 ribu orang, sejalan dengan Tingkat Pengangguran Terbuka (TPT) yang turun menjadi 5,01 persen pada Februari 2019.

Berdasarkan dari penjelasan latar belakang dapat kita lihat perkembangan IPM, pengeluaran pemerintah bidang pendidikan, kesehatan dan TPAK. IPM tertinggi pada tahun 2019. Fenomena yang terjadi saat IPM di Indonesia daritahun ke tahunmengalami peningkatan terutama dalam kurunwaktu 2010 hingga 2019, hal ini berbandingg terbalikdengan kondisi pengeluaran pemerintah yang justru mengalami fluktuasi. Seperti pada tahun 2016 pengeluaran pemerintah disektor pendidikan mengalami penurunan dibandingkantahun sebelumnya, namun disisi IPM pada tahun yang sama justru mengalami peningkatan, hal initentu tidak sesuai engan teori 
yang dikemukakan oleh (Wahid, 2012) yang menyatakan bahwa investasi dalam hal pendidikan mutlak dibutuhkankarena alokasi anggaran pengeluaran pemerintah terhadap pendidikan merupakan wujud nyata darii investasi untuk meningkatkan proeduktivitas masyarakat. Karenanya fenomena ditahun 2016 dimana pengeluaran pemerintah meningkat dan IPM menurun. Maka dibutuhkan penelitian lebih lanjut.

Sedangkan pada pengeluaran pemerintah sektor kesehatan pada tabel diatas mengalami fluktuasi. padatahun 2011 dan tahun 2014 pegeluaran pemerintah sektor kesehatan mengalami penurunan sedangkan IPM meningkat dari tahunke tahun.Hal ini tentunya tidak sesuaii dengan teori yang dikemukakan oleh (Todoro \& Smith, 2003) bahwa pengeluaran pemerintah pada sektor anggaran yang dikeluarkan untuk memenuhi salah satu hak dasar untuk memperoleh pelayanan kesehatan berupa fasilitas dan pelayanan kesehatan merupakan prasyarat bagi peningkatan produktivitas masyarakat. Meningkatnya anggaran pemerintah dalam bidang kesehatan tentunya akan meningkatkan produktivitas penduduk sehingga dapat meningkatkan pembangunan manusia. Teori tersebut didukung oleh penelitian Suparno (2014) yang menyebutkan bahwa pengeluarann pemerintah sektor pendidikan berpengaruhpositif dan signifikan terhadapp IPM di Provinsi Kalimantan Timur.

Kemudian, TPAK dalam Tabel diatas juga mengalami kondisi yang fluktuasi. Pada tahun2013 sampai dengan 2015TPAK mengalami penurunan setiap tahunnya, sedangkan disisi lain variabel IPM mengalami peningkatan setiap tahunnya. Peningkatan partisipasiangkatan kerja menunjukkan bahwa meningkatnya kesadaran masyarakat akan pentingnya bekerja yaang juga dapat menunjukkan peningkatan dalam kualitas sumberdayamanusia. Ketika produktivitas tenaga kerja meningkat maka hal tersebut dapat mempengaruhi daya jualnya dalam artian upah yang akan diterima bertambah dan kesejahteraan manusia akan meningkat, Saragih (2019). Dalam penelitian Zain \& Ayunada (2013) mendapatkan hasil bahwa TPAK berpengaruh posiitif dan signiifikan terhadap IPM di Kabupaten/Kota di Provinsi Jawa Timur.

\section{TINJAUAN TEORITIS}

\section{Indeks Pembangunan Manusia}

IPM adalah suatu tolak ukur angka kesejahteraan suatu daerah atau negara yang dilihat berdasarkan tiga dimens iyaitu: angkaa harapan hiidup paada waktu lahir, angka haraapan lama sekolaah dan rata-rata lamma sekolah, dan kemampuan daya beli. (Putri 2018). Pembangunan manusia adalah upaya yang dilakukan untuk memperluas peluang penduduk untuk mencapai hidup layak yang secara umum dapat dilakukan melalui peningkatan kapasitas dasar dan daya beli. (Laisina,2015).

\section{Pengeluaran Pemerintah}

Menurut (Sukirno,2009). Pengeluaran pemerintah yaitu bagian dari kebijakan fiskal, yang merupakan suatu tindakan pemerintah untuk mengatur jalannya perekonomian dengan cara menentukan besarnya penerimaan dan pengeluaran pemerintah setiap tahunnya, yang tercermin dalam dokumen Anggaran Pendapatan Belanja Negara untuk nasional dan Anggaran Pendapatan Belanja Daerah untuk daerah atau regional. Menurut(Musgrave,2006) perkembangan pengeluaran negara sejalan dengan tahap perkembangan ekonomi dari suatu negara. Pengeluaran pemerintah tetap diperlukan utamanya untuk meningkatkan kesejahteraan masyarakat.

\section{Pengeluaran Pemerintah Bidang Pendidikan}

Dalam arti luas, pendidikan adalah memainkan peran yang semakin besar untuk mewujudkan perubahan mendasar dalam cara manusia hidup dan bertindal. Pendidikan pun menjadi investasi masa depan, karena dengan pendidikan manusia mampu menyesuaikan cara berfikirnya untuk mengembangkan segala potensi diri dan mengambil peran dalam kehidupan. Pendidikan menjadi modal dalam mengantarkan negara dan masyarakat berinteraksi pada skala global menghadapi tantangan dunia yang semakin kompleks (BPS,2018)

\section{Pengeluaran Pemerintah Bidang Kesehatan}

Pengeluaran pemerintah pada bidang kesehatan merupakan upaya untuk memenuhi salah satu hak dasar masyarakat yaitu untuk memperoleh pelayanan penyerapan tenaga kerja yang dapat berpengaruh terhadap kesejahteraan masyarakat. Dimana dengan adanya pergeseran kegiatan masyarakat dari sektor tradisional ke sektor modern untuk mendapatkan pendapatan 
perkapita masyarakat juga dapat meringanan beban fisik masyarakat yang dapat berpengaruh kepada kondisi kesehatan masyarakat. Pembangunan bidang kesehatan merupakan salah satu prioritas pembangunan nasional dalam RPJMN Tahun 2015-2019. Pemerintah mengalokasi anggaran sebesar 5\%(lima Persen) dari anggaran pendapatan dan belanja negaraa diluar gaji, sementara pemerintah provinsi dan kabupaten/kota mengalokasikan anggaran kesehatan sebesar 10\% (Sepuluh Persen) dari anggaran pendapatandan belanja daerah diluar gaji. Tujuannya adalah untuk tercapainya derajat kesehatan yang terus membaik dan penggunaan kesehatan sesuai dengan Undang-Undang dasar 1945 Pasal $28 \mathrm{H}$ ayat 1 dan Undang-Undang Nomor 23 Tahun 1992 tentang kesehatan. (Kuncoro,2013).

\section{Tingkat Partisipasi Angkata Kerja}

Menurut (Simanjuntak, 2010) tenaga kerja adalah penduduk yang sudah atau sedangbekerja yang sedang mencari pekerjaaan dan yang melaksanakan kegiatan lain seperti bersekolah dan mengurus rumahtangga. Angkatankerja adalah penududuk yang berumur 10 tahun keatas yang mampu terlibat dalam proses produksi. Yang digolongkan bekerja yaitu mereka yang sudah mengerti dalam menghasilkan barang atau jasa untuk mendapatkan penghasilan dan lama waktu berkerja paling sedikit 1 jam dalam waktu tidak seminggu dan tidak boleh putus ataupun berhenti. TPAK merupakan ukuran proporsi penduduk usia kerja yang terlibat aktif dipasar tenaga kerja, baik itu dengan bekerja atau mereka yang sedang mencari pekerjaan, yang memberikan ukuran relatif dari pasokan tenaga kerja yang tersedia untuk terlibat dalam proses produksi barang dan jasa (BPS,2012).

\section{Kerangka Konseptual}

Kerangka konseptual menjelaskan pengaruh antara variabel bebas dan variabel terikat, yaitu pengaruh pengeluaran pemerintah sektor pendidikan $\left(\mathrm{X}_{1}\right)$, pengeluaran pemerintah sektor kesehatan $\left(\mathrm{X}_{2}\right)$ dan tingkat partisipasi angkatan kerja $\left(\mathrm{X}_{3}\right)$ terhadap indeks pembangunan manusia (Y) yang akan di uji secara parsial, dan secara bersama-sama seluruh variabel independen terhadap dependen.

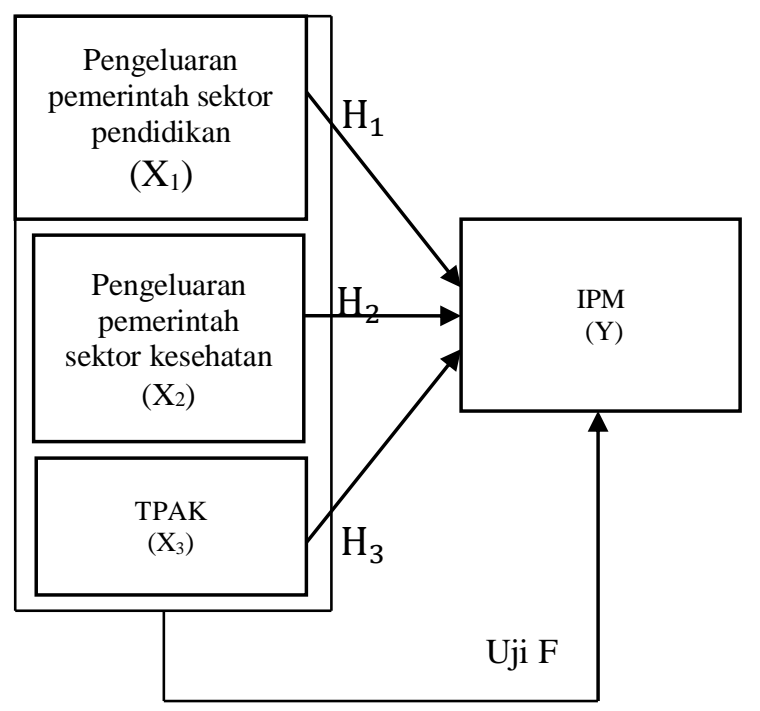

\section{Hipotesis}

Hipotesis pada penelitian ini sebagai berikut :

$\mathrm{H}_{1}$ : Diduga Pengeluaran pemerintah bidang pendidikan berpengaruh secara positif dan signifikan terhadap IPM.

$\mathrm{H}_{2}$ : Diduga Pengeluaran pemerintah bidang kesehatan berpengaruh secara positif dan signifikan terhadap IPM.

$\mathrm{H}_{3}$ : Diduga TPAK berpengaruh secara positif dan signifikan terhadap IPM.

\section{METODE PENELITIAN}

\section{Teknik Pengumpulan Data}

Teknik pengumpulan data dalam penelitian ini adalah dokumentasi. Dokumentasi merupakan tekni pengumpulan data yang bersumber dari literatur-literatur perpustakaan, laporan-laporan penelitian ebelumnya atau catatan-catatan yang mendukug penelitian iniseperti buku, internet dan literatur lainnya.

\section{Definisi Operasionalisasi Variabel}

Variabel adalah gambaran nyata mengenai fenomena-fenomena penelitian. Sedangkan operasional variabel merupakan petunjuk atau cara untuk mengukur variabel dalam penelitian.

1. IPM sebagai Variabel (Y)

IPM yaitu alat ukur kesejahteraan suatu negara yang dilihat dari kesehatan, pendidikan dan ekonomi yang diukur alam satuan persen $(\%)$.

2. Pengeluaran pemerintah bidang pendidikan sebagai (X1)

Pengeluaran pemerintah bidang pendidikan yaitu investasi dalam hal bidang pendidikan yang diukur dalam satuan Milliar Rupiah. 
3. Pengeluaran pemerintah bidang kesehatan sebagai (X2)

Pengeluaran pemerintah bidang kesehatan yaitu investasi dalam bidang kesehatan, diukur dalam satuan Milliar Rupiah.

4. TPAK sebagai variabel (X3)

TPAK merupakan indikator ketenagakerjaan yang memberikan gambaran tentang penduduk yang aktif secara ekonomidalam kegiatan sehariari yang merunjuk pada uatu waktu dalam periode survei yang diukur galam satuan persen.

\section{Metode Analisis Data}

\section{Model Regresi Linear Ordinary Least Square}

Dalam penelitian ini erdapat lebih dari satu variabel independent, maka dari itu digunakan persamaan regresi linier berganda (multyple regression). Model persamaan regresi yang dapat diperoleh dalam analisis penelitian ini adalah:

Dimana:

$$
\mathrm{Y}=\alpha+\beta_{1} X_{1}+\beta_{2} X_{2}+\beta_{3} X_{3}+e
$$

$\mathrm{Y}=\mathrm{IPM}$

$X_{1}=$ Pengeluaran pemerintah bidang pendidikan

$X_{2}=$ Pengeluaran pemerintah bidang kesehatan

$X_{3}=$ TPAK

$\alpha=$ Konstanta

$\beta=$ Koefisien Regresi

$\mathrm{e}=$ Standar error

\section{Uji Normalitas}

Uji normalitas adalah untuk mengetahui apakah residualberdistribusi secara normal atau tidak. Jika nilai probability dari statistik J-B lebih besar dari taraf kepercayaan 5\% $(0,05)$ berarti bahwa residualdata berdistribusi normal. Sebaliknya jika nilai probabilitydari statistik J-B lebih kecil dari taraf kepercayaan 5\% $(0,05)$ berarti bahwa residual data tidak berdistribusi ormal (Winarno,2009).

\section{Uji Asumsi Klasik}

Uji asumsi klasik secara individu (parsial) meganalisis variabel yang telah ditetapkan diatas untu melihat pengaruh nyata terhadap pelaksanaan program pelatihn dengan meminimalisir tingkat ksalahan.

\section{Uji Multikolinieritas}

Uji mulitikolinieritas bertujuan untuk menguji apakah dalam model regresi ditemukan adanya korelasi antar variabel bebas. Uji multikolnieritas digunakan karena pada analisis regesi terdapat asumsi yang mensyaratkan bahwa variabel indenpenden harus terbebas dari gejala multikolinieritas atau tidk terjadi antar variabel indenpenden. Multikolinieritas dapat didetksi dengan nilai determinasi yang tinggi dengn diikuti nilai $F$ statistik yang sangat tinggi, serta tidak ada atau hanya sedikit nilai t-test yang sigifikan. Koefisien matrik korelasi antara variabel yang inggi $(>0,8)$. Jika korelasi antar variabel bebas kurang dari 0,8 maka dapat dikatakan tidak ada multikolinieritas.

Pengujian multikolinieritas dapat juga dilakukan dengan menghitung nilai torelance dan varians inflation factor (VIF)dari tiap-tiap variabel indenpenden. Apabila nilai torelance $<0,10$ dan VIF $<10$ maka terjadi multikolineritas dan sebaliknya apabila nilai torelance $>0,10$ dan VIF $<10$ maka tidak terjadi multikolinieritas dengan kata lain korelasi yang terdapat antar variabel independen masih dapat ditolerir.

\section{Uji Autokorelasi}

Uji auto korelasi merupakan korelasi antara variabel gangguan satu dengan gangguan lainnya. Akibat adanya autokorelasi adalah parameter yang diestamasi menjadi bias dan variasinya tidak minimum sehingga tidak efisien. Uji auto korelasi bertujuan untuk menguji apakah dalam model regresi ada korelasi antara kesalahan pengganggu pada periode $\mathrm{t}$ dengan kesalahan pengganggunpada periode $\mathrm{t}-1$ (sebelumnya).

\section{Uji Heteroskedastisitas}

Heteroskedastisitas adalah situasi penyebaran data yang tidak sama atau tidak samanya variansi uji signifikan tidak valid. Uji Heteroskedastisitas bertujuan untuk mengetahui apakah dalam sebuah model regresi terjadi ketidaksamaan varian residual (kesalahan penganggu) dari satu pegamatan ke pengamatan lainnya. Salah satu cara mendeteksi masalah heterokedastisitas adalah menggunakan uji white. Uji white dilakukan dengan meregresikan semua variabel bebas terhadap nilai absolut residual (Winarno, 2015). Menurut (Widarjono,2013) jika nilai probabilitas chi square > 0,05 maka tidak terjadi heteroskedastisitas.

\section{Pengujian Hipotesis}

\section{Uji t-Statistik}

Pengujian parsial dilakukan untuk melihat seberapa besar pengaruh variabel independen 
terhadap variabel dependen (Ghozali, 2006). Berikut kriteria pengujiannya:

1. jika $t_{\text {hitung }}>t_{\text {tabel }}$ dengan tingkat signifikan $5 \%$ atau 0.05 , variabel bebas berpengaruh terhadap variabel terikatnya.

2. jika $t_{\text {hitung }}<t_{\text {tabel }}$ dengan tingkat signifikan $5 \%$ variabel bebas tidak berpengaruh terhadap variabel terikatnya.

\section{Uji F-statistik}

Uji simultan (Uji F) dilakukan untuk mengetahui pengaruh keseluruhan variabel independen terhadap variabel dependennya (Ghozali, 2006). Kriteria pengujiannya yaitu:

1. Jika $F_{\text {hitung }}>F_{\text {tabel }}$ dengan ketentuan tingkat signifikan 5\%, secara bersama variabel bebas memiliki pengaruh signifikan terhadap variabel terikatnya.

2. Jika $F_{\text {hitung }}<\mathrm{F}_{\text {tabel }}$ dengan ketentuan tingkat signifikan 5\%, secara bersama variabel bebas tidak memiliki berpengaruh terhadap variabel dependen.

\section{Koefisien Determinasi $\left(\mathbf{R}^{\mathbf{2}}\right)$}

Pengujian koefisien determinasi bertujuan melihat seberapa besar pengaruh variabel independen terhadap perubahan variabel terikat. Dalam (Gujarati, 2012), nilai koefisien determinasi sebesar 0-1. Jika $R^{2}$ semakin mendekati 1 berarti semakin kuat pengaruhnya, jika $R^{2}$ kecil mendekati 0 berarti semakin kecil pengaruhnya.

\section{Koefisien Korelasi (R)}

Menurut (Sugiyono,2010) koefisien korelasi bertujuan untuk mengetahui kuat tidaknya hubunganantara variabel $\mathrm{X}$ dan variabel $\mathrm{Y}$. Koefisien korelasi diberi simbol r. Nilai koefisien korelasi in paking kecil -1 dan paling besar +1 .

\section{HASIL PENELITIAN DAN PEMBAHASAN}

Hasil Penelitian

Hasil Pengujian Normalitas

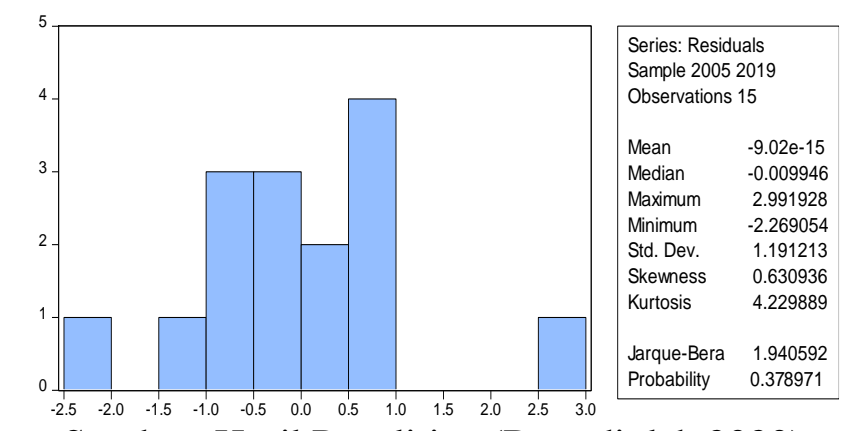

Sumber: Hasil Penelitian (Data diolah,2020).

Dari Gambar diatas, dapat dijelaskan bahwa nilai dari Jarque-Bera atau nilai dari probabilitas pada Jarque-Bera pada penelitian ini sebesar 0.677422 lebih besar dari alpha $5 \%$ atau $0.378971>0.05$. Artinya dalam penelitian ini data berdistribusi secara normal.

\section{Hasil Uji Asumsi Klasik \\ Hasil Uji Multikolinieritas}

\begin{tabular}{|c|c|c|c|}
\hline \multicolumn{4}{|c|}{ Variance Inflation Factors } \\
\hline \multicolumn{3}{|c|}{ Date: 07/12/20 Time: 11:42 } \\
\hline \multicolumn{3}{|c|}{ Sample: 2005 2019 } \\
\hline \multirow{3}{*}{ Included observations: 15 } \\
\hline \hline Variable & Coefficient & Uncent & Centered \\
& Variance & VIF & VIF \\
\hline \hline C & 906.3383 & 7527.7 & NA \\
& & 94 & \\
\hline X1 & $4.07 \mathrm{E}-10$ & 39.958 & 5.249096 \\
& & 10 & \\
\hline X2 & $1.40 \mathrm{E}-09$ & 17.635 & 5.138659 \\
& & 28 & \\
\hline X3 & 0.204886 & 7637.6 & 1.050223 \\
& & 49 & \\
\hline
\end{tabular}

Sumber: Hasil Penelitian, (Data Diolah,2020).

Berdasarkan Tabel diatas, dapat dijelaskan bahwa nilai centered VIF pada variabel $\mathrm{X} 1, \mathrm{X} 2$ dan X3 tidak adanya hubungan korelasi karena nilai dari multiko linieritas setiap variabel independennya berada dibawah 10, maka dalam penelitian ini tidak ada gangguan multikolinieritas.

\section{Hasil Pengujian Hasil Pengujian Autokorelasi}

\begin{tabular}{|c|c|c|c|}
\hline \multicolumn{4}{|c|}{ Breusch-Godfrey Serial Correlation LM Test: } \\
\hline F-statistic & 0.2564 & Prob. F(2,9) & 0.7793 \\
\hline
\end{tabular}




\begin{tabular}{|l|c|l|l|}
\hline & 10 & & \\
\hline $\begin{array}{l}\text { Obs*R- } \\
\text { squared }\end{array}$ & $\begin{array}{c}0.8086 \\
25\end{array}$ & $\begin{array}{c}\text { Prob. Chi- } \\
\text { Square(2) }\end{array}$ & 0.6674 \\
\hline
\end{tabular}

Sumber: Hasil Penelitian, (Data diolah,2020).

Berdasarkan Tabel diatas, dapat dilihat bahwa nilai probabilitas dari Chi-Square sebesar 0.6674 lebih besar dari alpha 5\% atau 0.05 $(0.6674>0.05)$. Artinya dalam penelitian ini tidak ada gangguan autokorelasi.

\section{Hasil Pengujian Heteroskedastisitas}

Heteroskedasticity Test: White

\begin{tabular}{lrcc}
\hline \hline & 0.5215 & & \\
F-statistic & 38 & Prob. F(3,11) & 0.6762 \\
Obs*R- & 1.8678 & Prob. Chi- & \\
squared & 80 & Square(3) & 0.6003 \\
Scaled & 1.6222 & Prob. Chi- & \\
explained SS & 19 & Square(3) & 0.6544 \\
\hline \hline
\end{tabular}

Sumber: Hasil Penelitian, 2020 (data diolah)

Berdasarkan Tabel diatas bahwa nilai probabilitas dari obs*R-Square > alpha 5\% $(0.6003>0.05)$ maka yang artinya bahwa penelitiannya terbebas dari heteroskedastisitas.

\section{Hasil Regresi Linier Berganda}

\begin{tabular}{|c|c|c|c|c|}
\hline \multicolumn{5}{|c|}{ Dependent Variable: Y } \\
\hline \multicolumn{5}{|c|}{ Method: Least Squares } \\
\hline \multicolumn{5}{|c|}{ Date: 07/12/20 Time: $11: 32$} \\
\hline \multicolumn{5}{|c|}{ Sample: 20052019} \\
\hline \multicolumn{5}{|c|}{ Included observations: 15} \\
\hline Variable & $\begin{array}{l}\text { Coefficie } \\
\mathrm{nt}\end{array}$ & $\begin{array}{l}\text { Std. } \\
\text { Error }\end{array}$ & $\begin{array}{l}\text { t- } \\
\text { Statisti } \\
\mathrm{c}\end{array}$ & Prob. \\
\hline $\mathrm{C}$ & 26.84885 & $\begin{array}{l}30.105 \\
45\end{array}$ & $\begin{array}{l}0.8918 \\
27\end{array}$ & 0.3916 \\
\hline $\mathrm{X} 1$ & $\begin{array}{l}-5.58 \mathrm{E}- \\
05\end{array}$ & $\begin{array}{l}2.02 \mathrm{E}- \\
05\end{array}$ & $\begin{array}{l}- \\
2.7656 \\
43\end{array}$ & 0.0184 \\
\hline $\mathrm{X} 2$ & 0.000118 & $\begin{array}{l}3.74 \mathrm{E}- \\
05\end{array}$ & $\begin{array}{l}3.1574 \\
05\end{array}$ & 0.0091 \\
\hline X3 & 0.666323 & $\begin{array}{l}0.4526 \\
43\end{array}$ & $\begin{array}{l}1.4720 \\
73\end{array}$ & 0.1690 \\
\hline R-squared & 0.504293 & $\begin{array}{l}\text { Mean } \\
\text { var }\end{array}$ & ependent & $\begin{array}{l}69.7046 \\
7\end{array}$ \\
\hline $\begin{array}{ll}\text { Adjusted R- } \\
\text { squared }\end{array}$ & 0.369101 & $\begin{array}{l}\text { S.D. } \\
\text { var }\end{array}$ & ependent & $\begin{array}{l}1.69190 \\
9\end{array}$ \\
\hline
\end{tabular}

\begin{tabular}{|l|l|l|l|}
\hline $\begin{array}{l}\text { S.E. of } \\
\text { regression }\end{array}$ & 1.343869 & $\begin{array}{l}\text { Akaike info } \\
\text { criterion }\end{array}$ & $\begin{array}{l}3.65216 \\
1\end{array}$ \\
\hline $\begin{array}{l}\text { Sum squared } \\
\text { resid }\end{array}$ & 19.86582 & Schwarz criterion & $\begin{array}{l}3.84097 \\
4\end{array}$ \\
\hline $\begin{array}{l}\text { Log } \\
\text { likelihood }\end{array}$ & 23.39121 & $\begin{array}{l}\text { Hannan-Quinn } \\
\text { criter. }\end{array}$ & $\begin{array}{l}3.65015 \\
0\end{array}$ \\
\hline F-statistic & 3.730183 & $\begin{array}{l}\text { Durbin-Watson } \\
\text { stat }\end{array}$ & $\begin{array}{l}2.29771 \\
9\end{array}$ \\
\hline $\begin{array}{l}\text { Prob(F- } \\
\text { statistic) }\end{array}$ & 0.045246 & & \\
\hline
\end{tabular}

Sumber: Hasil Penelitian (Data Diolah 2020).

Berdasarkan Tabel diatas dapat di interprestasikan hasil regresi linier berganda pada penelitian ini sebagai berikut:

\section{$\mathrm{Y}=26.84885-0,0000558 \mathrm{X} 1+0.000118 X 2+$ \\ $0.666323 \times 3$}

Dari persamaan diatas menujukkan bahwa:

1. nilai koefisien konstanta sebesar 26.84885, ini berarti apabila X1, X2 dan $\mathrm{X} 2$ dianggap konstan, maka $\mathrm{Y}$ sebesar 26.84885 persen.

2. Nilai koefisien dari X1 sebesar 0,0000558, ini berarti apabila terjadi peningkatan pada jumlah pengeluaran pemerintah bidang pendidikan (X1) sebesar 1 miliar maka akan menurunkan ipm (Y) sebesar 0,0000558 persen.

3. Nilai koefisien $\mathrm{X} 2$ sebesar 0.000118 , ini berarti apabila terjadi peningkatan pengeluaran pemerintah bidang kesehatan (X2) sebesar 1 miliar maka akan meningkatkan ipm (Y) sebesar 0.000118 persen.

4. Nilai koefisien X3 sebesar 0.666323, ini berarti apabila terjadi peningkatan pada tpak sebesar 1 persen maka akan meningkatkan ipm sebesar 0.666323 persen.

\section{Pengujian Hipotesis \\ Hasil Pengujian Parsial (Uji t)}

\begin{tabular}{|c|c|c|c|c|}
\hline $\begin{array}{c}\text { Variab } \\
\text { el } \\
\text { Bebas }\end{array}$ & $\begin{array}{c}\text { t- } \\
\text { statistik }\end{array}$ & t Tabel & Prob & Keterangan \\
\hline $\mathrm{X} 1$ & $\begin{array}{c}2.76564 \\
3\end{array}$ & & 0.0184 & \\
\hline $\mathrm{X} 2$ & $\begin{array}{c}3.15740 \\
5\end{array}$ & & 0.0091 & Signifikan \\
\cline { 1 - 2 } & & & & \\
\hline
\end{tabular}




\begin{tabular}{|c|c|l|l|l|}
\hline $\mathrm{X} 3$ & $\begin{array}{c}1.47207 \\
3\end{array}$ & & 0.1690 & $\begin{array}{l}\mathrm{T} . \\
\text { Signifikan }\end{array}$ \\
\hline
\end{tabular}

Sumber: Hasil Penelitian (Data Diolah, 2020).

Berdasarkan Tabel diatas dapat dilihat bahwa variabel $\mathrm{X} 1$ memiliki nilai $t_{\text {hitung }}$ sebesar $-2.765643>t_{\text {tabel }}-1.36343$, maka terima $\mathrm{H}_{1}$ dan tolak $\mathrm{H}_{0}$ yang artinya bahwa variabel $\mathrm{X} 1$ atau pengeluaran pemerintah bidang pendidikan berpengaruh negatif dan signifikan terhadap indeks pembangunan manusia. Variabel X2 memiliki nilai $t_{\text {hitung }}$ sebesar $3.157405>t_{\text {tabel }}$ 1.36343, maka terima $\mathrm{H}_{2}$ dan tolak $\mathrm{H}_{0}$ yang artinya bahwa variabel $\mathrm{X} 2$ atau pengeluaran pemerintah bidang kesehatan berpengaruh positif dan signifikan terhadap ipm. Variabel X3 memiliki nilai $t_{\text {hitung }}$ sebesar $1.472073>t_{\text {tabel }}$ 1.36343, maka terima $\mathrm{H}_{3}$ dan tolak $\mathrm{H}_{0}$ yang artinya bahwa variabe $\mathrm{X} 3$ atau tpak berpengaruh positif tapi tidak signifikan terhadap ipm.

\section{Hasil Pengujian Simultan (Uji F)}

\begin{tabular}{|c|c|c|c|}
\hline $\begin{array}{c}\text { F } \\
\text { Statistik }\end{array}$ & $\begin{array}{c}\text { F } \\
\text { Tabel }\end{array}$ & Probabilitas & Keterangan \\
\hline 3.730183 & 3.59 & 0.045246 & Signifikan \\
\hline
\end{tabular}

Sumber: Hasil Penelitian (data diolah 2020).

Berdasarkan pada Tabel di atas dapat dilihat bahwa nilai dari $\mathrm{F}_{\text {hitung }}$ pada penelitian ini sevesar 3.730183, sementara nilai dari $F_{\text {tabel }}$ diperoleh sebesar 3.59 dari alpha 0,05. Sehingga dapat diketahui bahwa nilai $\mathrm{F}_{\text {hitung }} 3.730183$ > 3.59, maka terima $\mathrm{H}_{1}$ dan tolak $\mathrm{H}_{0}$ yang artinya secara bersama-sama dengan tingkat kepercayaan 95\% viariabel pengeluaran pemerintah bidang pendidikan, pengeluaran pemerintah bidang kesehatan dan tpak berpengaruh positif dan signifikan terhadap ipm di Indonesia. Hal ini juga bisa dilihat dari probabilita uji $\mathrm{F}$ yang signifikan sebesar $0.045246<0,05$.

\section{Pengujian Koefisien Determinasi $\left(R^{2}\right)$}

\section{Hasil Pengujian Koefisien Determinasi dan Korelasi}

\begin{tabular}{|c|}
\hline Dependent Variable: $\mathrm{Y}$ \\
\hline Method: Least Squares \\
\hline Date: 07/12/20 Time: 11:32 \\
\hline Sample: 2005 2019 \\
\hline Included observations: 15 \\
\hline
\end{tabular}

\begin{tabular}{|c|c|c|c|c|}
\hline Variable & $\begin{array}{r}\text { Coefficie } \\
\text { nt }\end{array}$ & $\begin{array}{r}\text { Std. } \\
\text { Error }\end{array}$ & $\begin{array}{r}\mathrm{t}- \\
\text { Statisti } \\
\mathrm{c}\end{array}$ & Prob. \\
\hline $\mathrm{C}$ & 26.84885 & $\begin{array}{r}30.105 \\
45\end{array}$ & $\begin{array}{r}0.8918 \\
27\end{array}$ & 0.3916 \\
\hline $\mathrm{X} 1$ & $\begin{array}{r}-5.58 \mathrm{E}- \\
05\end{array}$ & $\begin{array}{r}2.02 \mathrm{E}- \\
05\end{array}$ & $\begin{array}{r}- \\
2.7656 \\
43\end{array}$ & 0.0184 \\
\hline $\mathrm{X} 2$ & 0.000118 & $\begin{array}{r}3.74 \mathrm{E}- \\
05\end{array}$ & $\begin{array}{r}3.1574 \\
05\end{array}$ & 0.0091 \\
\hline X3 & 0.666323 & $\begin{array}{r}0.4526 \\
43\end{array}$ & $\begin{array}{r}1.4720 \\
73\end{array}$ & 0.1690 \\
\hline R-squared & 0.504293 & \multicolumn{2}{|c|}{$\begin{array}{c}\text { Mean } \\
\text { dependent var }\end{array}$} & $\begin{array}{r}69.7046 \\
7\end{array}$ \\
\hline $\begin{array}{ll}\text { Adjusted } & \text { R- } \\
\text { squared } & \end{array}$ & 0.369101 & \multicolumn{2}{|c|}{$\begin{array}{l}\text { S.D. dependent } \\
\text { var }\end{array}$} & $\begin{array}{r}1.69190 \\
9\end{array}$ \\
\hline $\begin{array}{ll}\text { S.E. } & \text { of } \\
\text { regression }\end{array}$ & 1.343869 & \multicolumn{2}{|c|}{$\begin{array}{l}\text { Akaike info } \\
\text { criterion }\end{array}$} & $\begin{array}{r}3.65216 \\
1\end{array}$ \\
\hline $\begin{array}{l}\text { Sum } \\
\text { resid }\end{array}$ & 19.86582 & \multicolumn{2}{|c|}{$\begin{array}{l}\text { Schwarz } \\
\text { criterion }\end{array}$} & $\begin{array}{r}3.84097 \\
4\end{array}$ \\
\hline Log likelihood & 23.39121 & \multicolumn{2}{|c|}{$\begin{array}{l}\text { Hannan-Quinn } \\
\text { criter. }\end{array}$} & $\begin{array}{r}3.65015 \\
0\end{array}$ \\
\hline F-statistic & 3.730183 & \multicolumn{2}{|c|}{$\begin{array}{l}\text { Durbin-Watson } \\
\text { stat }\end{array}$} & $\begin{array}{r}2.29771 \\
9\end{array}$ \\
\hline Prob(F-statistic) & 0.045246 & & & \\
\hline
\end{tabular}

Sumber: Hasil Penelitian, (Data diolah 2020).

Berdasarkan Tabel diatas, hasil nilai Adjusted R-Squared dalam penelitian ini adalah sebesar 0.369101, hal ini menunjukkan bahwa kemampuan antara variabel bebas dalam menimbulkan keberadaan variabel terikat dalam penelitian ini adalah sebesar $36,91 \%$ sedangkan $63,09 \%$ lainnya dipengaruhi oleh variabel di luar penelitian ini.

\section{Pengujian Koefisien Korelasi}

Berdasarkan Tabel dapat dilihat bahwa nilai koefisien korelasi (r) atau $\mathrm{R}$ squared adalah sebesar 0.504293 atau $50,42 \%$, maka pada penelitian ini dapat disimpulkan bahwa terdapat hubungan korelasi yang kuat antara variabel bebas dengan variabel terikat.

\section{Pembahasan}

Dari hasil pengujian secara parsial seperti pada Tabel 4.5 maka keterkaitan variabel bebas 
dengan variabel terikat pada penelitian ini dapat dijelaskan sebagai berikut.

\section{Pengaruh Pengeluaran Pemerintah Bidang Pendidikan terhadap IPM}

Berdasarkan hasil pengujian secara parsial pada variabel pengeluaran pemerintah bidang pendidikan terhadap ipm dalam penelitian ini berpengaruh negatif dan signifikan. Nilai koefisiennya bernilai negatif dapat terjadi dikarenakan naiknya jumlah pengeluaran pemerintah bidang pendidikan dikeluarkan tidak dibarengi dengan besarnya jumlah atau hasil yang diterima. Selain itu, dapat juga disebabkan karena pengeluaran pemerintah bidang pendidikan selama ini belum cukup berkualitas dan tepat sasaran sehingga pengeluaran pemerintah belum mampu memberi hasil maksimal terhadap ipm di Indonesia

\section{Pengaruh Pengeluaran Pemerintah Bidang Kesehatan terhadap IPM}

Berdasarkan hasil pengujian secara parsial pada variabel pengeluaran pemerintah bidang kesehatan terhadap ipm dalam penelitian ini berpengaruh positif dan signifikan. Artinya setiap peningkatan jumlah pengeluaran pemerintah bidang kesehatan meningkat maka akan meningkatkan ipm.

\section{Pengaruh Tingkat Partisipasi Angkatan Kerja terhadap IPM}

Berdasarkan hasil pengujian secara parsial pada variabel TPAK terhadap IPM dalam penelitian ini berpengaruh positif dan tapi tidak signifikan. Artinya TPAK memiliki pengaruh terhadap IPM, namun tidak terlalu besar pengaruhnya.

Hasil penelitian ini sejalan dengan penelitian yang dilakukan oleh Saragih (2019) yang mendapatkan hasil pada penelitiannya bahwa TPAK berpengaruh secara positif tapi tidak signifikan terhadap IPM di Kabupaten Serdang Bedagai.

Tidak signifikannya TPAK pada penelitian ini dapat disebabkan karena banyaknya jumlah penduduk usia kerja yang tidak terserap dengan baik kedalam lapangan pekerjaan yang tersedia. hal tersebut juga dapat disebabkan karena kualitas pendidikan yang dimiliki penduduk usia kerja belum memadai, selain itu dapat juga disebabkan karena ketersediaan lapangan pekerjaan yang telalu sedikit.

\section{Kesimpulan}

Berdasarkan hasil analisis dari pembahasan dalam penelitian ini dapat diberi kesimpulan sebagai berikut:

1. Secara parsial pada penelitian ini, pengeluaran pemerintah bidang pendidikan berpengaruh negatif dan signifikan terhadap ipm di Indonesia

2. Secara parsial pada penelitian ini, variabel pengeluaran pemerintah bidang kesehatan berpengaruh positif dan signifikan terhadap ipm di Indonesia

3. Secara parsial pada penelitian ini, variabel tingkat partisipasi angkatan kerja berpengaruh positif tapi tidak signifikan terhadap ipm di I ndonesia.

\section{Saran}

Berdasarkan dari hasil penelitian yang telah dilakukan maka penulis dapat memberikan beberapa saran yaitu:

1. Disarankan kepada pemerintah untuk dapat meningkatkan pengeluaran pemerintah di setiap bidang dengan melakukan kebijakan-kebijakan yang tepat sasaran, sehingga nantinya pengeluaran pemerintah akan selalu meningkatkan terhadap IPM di Indonesia.

2. Disarankan kepada peneliti yang tertarik pada variabel ini disarankan untuk mengambil rentan waktu yang lebih lama dan menambahkan variabel-variabel lainnya, supaya dapat memberikan hasil yang lebih relevan terhadap IPM Indonesia.

3. Diharapkan hasil penelitian ini dapat memberikan ilmu pemahaman kepada masyarakat tentang permasalahanpermasalahan yang ada di Indonesia ini khususnya dengan masalah pengeluaran anggaran pemerintah dibidang pendidikan, bidang kesehatan, tingkat kemiskinan, TPAK dan IPM di Indonesia.

\section{DAFTAR PUSTAKA}

BPS. 2012. TPAK. Jakarta: BPS Indonesia

BPS. 2018. IPM. Jakarta: BPS Indonesia.

BPS. 2019. IPM. Jakarta: BPS Indonesia.

Gujarati, D. N,. 2006. Ekonometrika Dasar. Jakarta: Penerbit Erlangga.

Kementrian Keuangan, 2018. Alokasi Anggaran Belanjan Pemerintah Pusat. 
Kuncoro, Mudrajat. 2013. Menulis Skripsi/tesis

Dalam 60 Hari. Yogyakarta: UPP STIM YKPN. Lampung

Nur Vadila Putri, Muhammad Yusri Z, Sanusi fattah. 2018. Pengeluaran Pemerintah dan Indeks Pembangunan Manusia di Kota Makassar. Jurnal Analisis, Vol. 7, No 1, Tahun 2018

Simanjuntak. 2010. Ekonomi Sumber Daya Manusia. Jakarta.

Sugiyono. 2010. Metode Penelitian Pendidikan Pendekatan Kuantitatif, Kualitatif, R\&D. Bandung: Alfabeta

Sukirno, Sadono. 2009. Mikro Ekonomi Teori Pengatar. Edisi Ketiga, Rajawali Pers, Jakarta.

Todoro, Michael P \& Smith, S.C. 2003. Economic Deplopment, Eight Edition. Jakarta: PT Gelora Aksara Pratama

Wahid, Bila. A. 2012. Pengaruh Pengeluaran Pemerintah Terhadap Indeks Pembangunan Manusia Melalui Pertumbuhan Ekonomi. Makassar.

Zain \& Ayunada. (2013). Analisis Statistika Faktor Yang Mempengaruhi Indeks Pembangunan Manusia di Kabupaten/Kota Provinsi Jawa Timur dengan Menggunakan Regresi Panel. Jurnal Sains dan Seni Pomits, 2(2): 2337-2530 